reduced the effectiveness of the second dose. This was probably due to the lower osmotic susceptibility of $P$ mirabilis compared with $E$ coli, ${ }^{13}$ the reduced efficacy of the second dose reflecting the selection of an osmotically stable fraction of the population during the first cycle of drug exposure. The osmolality of the broth used $(325 \mathrm{mmol}(\mathrm{mOsm}) / \mathrm{kg})$ is within the normal range for human urine, which may, however, be much higher. At higher osmolalities $E$ coli is similarly protected and, conversely, at lower osmolalities $P$ mirabilis is more susceptible to antibioticinduced lysis. ${ }^{13}$ High fluid intake has been recommended in the treatment of urinary tract infection on other grounds, ${ }^{\prime}$ but an additional benefit might accrue in treatment with $\beta$-lactam antibiotics because of the consequent reduction in urinary osmolality.

Charlton et $a l^{2}$ successfully treated urinary infection in nonpregnant women in general practice with amoxycillin, $500 \mathrm{mg}$ three times a day for three days, and observed no advantage when treatment was extended for 10 days. Our findings offer microbiological evidence that similar success may be achieved by reducing the dose as well as the length of treatment.

\section{References}

1 Cattell, W R, et al, Urinary Tract Infection, ed F O'Grady and W Brumfitt, p 212. London, Oxford University Press, 1968.

2 Charlton, C A C, et al, British Medical fournal, 1976, 1, 124.

${ }^{3}$ Greenwood, D, and O'Grady, F, fournal of infectious Diseases, 1973, 128, 211

${ }^{4}$ O'Grady, F, et al, British fournal of Experimental Pathology, 1973, 54, 283.

${ }^{5}$ O'Callaghan, C H, et al, Antimicrobial Agents and Chemotherapy, 1976, 9, 511.

6 Shand, D G, et al, Lancet, 1970, 1, 1035

' Shand, D G, et al, British fournal of Urology, 1968, 40, 196.

${ }^{8}$ Greenwood, D, and O'Grady, F, fournal of Clinical Pathology, 1976, 29, 162.

${ }^{9}$ Greenwood, D, and O'Grady, F, Chemotherapy. In press.

10 Greenwood, D, and O'Grady, F, Fournal of Infectious Diseases, 1973, 128, 791.

${ }^{11}$ Spratt, B G, Proceedings of the National Academy of Sciences of the United States of America, 1975, 72, 2999.

12 Greenwood, D, and O'Grady, F, Fournal of Clinical Pathology, 1973, 26, 1.

13 Greenwood, D, and O'Grady, F, British fournal of Experimental Pathology, 1972, 53, 457.

(Accepted 21 fuly 1977)

\title{
Minoxidil for severe hypertension after failure of other hypotensive drugs
}

\author{
B L DEVINE， R FIFE， P M TRUST
}

British Medical fournal, 1977, 2, 667-669

\section{Summary}

Forty-four patients with severe hypertension who were resistant to treatment with more conventional hypotensive drugs or could not tolerate the side effects were treated with minoxidil, a potent peripheral vasodilator. $A$ beta-blocking drug and a diuretic were used routinely to control, respectively, the tachycardia and fluid retention caused by minoxidil. During treatment the outpatient supine blood pressure fell from a mean of $221 / 134 \mathrm{~mm} \mathrm{Hg}$ to $162 / 98 \mathrm{~mm} \mathrm{Hg}$. Eleven patients required additional or alternative hypotensive agents before blood pressure was adequately controlled. Side effects were minor, although the invariable hirsuties caused by minoxidil was unacceptable to three women.

The possibility of cardiotoxic effects, raised by early studies in dogs, has not been excluded, and therefore this drug should be used only in patients with severe hypertension. In such patients minoxidil appears to be most effective.

\section{Introduction}

Minoxidil has recently become available on trial in Britain for

Division of Medicine, Royal Infirmary, Glasgow

B L DEVINE, MB, MRCP, medical registrar

R FIFE, MB, FRCP, consultant physician

MRC Blood Pressure Unit, Western Infirmary, Glasgow

P M TRUST, MB, BS, clinical scientist treating patients with severe hypertension in whom conventional treatment has failed to control blood pressure. ${ }^{1}$ We describe here the use of minoxidil in 44 such patients.

\section{Patients and methods}

All the patients had diastolic blood pressures (fifth Korotkoff phase; the mean of the last three readings in the outpatient department, while sitting or lying) of over $120 \mathrm{~mm} \mathrm{Hg}$ despite treatment with other hypotensive drugs. Previous hypotensive treatment (table I) had been given in full dosage or had produced intolerable side effects.

Ten patients had been in the malignant phase of hypertension, 14 had had a stroke, nine had had congestive cardiac failure, and five complained of angina of effort. Twenty-two patients had renal failure before starting minoxidil; their blood urea concentrations were consistently over $7 \mathrm{mmol} / 1(42 \mathrm{mg} / 100 \mathrm{ml})$ and serum creatinine concentrations over $120 \mu \mathrm{mol} / 1(1.4 \mathrm{mg} / 100 \mathrm{ml})$.

The patients were all admitted to hospital before starting minoxidil and the following values were measured: full blood count including platelets; serum creatinine, urea, and electrolyte concentrations; cardiac enzymes (lactate dehydrogenase, creatine phosphokinase); serum aspartate and alanine aminotransferase and serum bilirubin concentrations; and fasting blood sugar concentrations. An electrocardiogram (ECG) was recorded and a chest radiograph taken. These investigations were repeated at regular intervals. In general hypotensive drugs other than beta-adrenergic receptor blocking agents and diuretics were withdrawn before starting minoxidil. Beta-blockers and diuretics were continued since previous clinical experience ${ }^{2-6}$ had established the need for these drugs to combat, respectively, tachycardia and sodium retention. Except for the diuretic, which was given once in the morning, other drugs were taken twice daily. Minoxidil was started at a dose of $2.5 \mathrm{mg}$ on the first day and increased over four days to $40 \mathrm{mg}$ if required.

The blood pressure, measured with a traditional clinical sphygmomanometer, and pulse rate were recorded while supine, standing, and again while standing after exercise before each dose of minoxidil was given. The dose was not increased if the diastolic blood pressure fell below $90 \mathrm{~mm} \mathrm{Hg}$. 


\section{Results}

Patients were followed for up to two years. The total experience with minoxidil amounted to 505 patient-months.

\section{BLOOD PRESSURE}

Supine blood pressure fell significantly in all patients while they were in the ward (table II). There was no further fall in blood pressure on standing before or after exercise except in four patients who, because of very severe hypertension, had continued to receive additional treatment with bethanidine (2), methyldopa (1), or prazosin (1). After release from hospital the highly significant fall of blood pressure was maintained in the group as a whole (table II), although the response in individual patients varied considerably and the diastolic pressure remained over $100 \mathrm{~mm} \mathrm{Hg}$ in seven patients (table I).

DRUGS

After release from hospital the dose of minoxidil was adjusted as necessary, being increased in 14 patients (maximum $60 \mathrm{mg}$ daily) and reduced in four others (minimum $2.5 \mathrm{mg} /$ day); the average daily maintenance dose was $26.4 \mathrm{mg}$. The details of beta-blocker, usually propranolol, and diuretic treatment are shown in table I.

\section{PATIENTS WITHDRAWN FROM THE STUDY}

During the trial four patients died and six were withdrawn. Two men complained of central chest pain while at home and died with presumed myocardial infarction. One of these (case 14) had been
TABLE II-Supine blood pressure ( $\mathrm{mm} \mathrm{Hg}$ ) measured before and during minoxidil treatment in the ward and at outpatient attendances. Values are means $\pm S D$

\begin{tabular}{l|c|c}
\hline & Ward & Outpatient \\
\hline Before minoxidil & $\begin{array}{r}215 / 130 \pm 27 \cdot 0 / 15 \cdot 0 \\
158 / 94 \pm 19 \cdot 5 / 10 \cdot 2\end{array}$ & $\begin{array}{r}221 / 134+23 \cdot 4 / 12 \cdot 2 \\
162 / 98 \pm 27 \cdot 4 / 15 \cdot 7\end{array}$ \\
\hline
\end{tabular}

taking minoxidil for 10 months but had failed to take the tablets during the last two weeks; the other patient (case 40) died after four months' treatment with minoxidil and one week before death his blood pressure was well controlled. Another man (case 43), who had unilateral renal artery stenosis and had had a leaking aortic aneurysm repaired, developed sudden severe abdominal pain. Laparotomy showed no cause for the pain and an attempt to reconstruct the stenosed renal artery was unsuccessful. He died with renal failure three days later. The fourth patient (case 44) died from a massive intracerebral haemorrhage six weeks after starting minoxidil. Although his blood pressure was controlled while in the ward, very high readings were recorded when he was an outpatient despite his continuing treatment with minoxidil, and when he was readmitted the diastolic pressure was $155 \mathrm{~mm} \mathrm{Hg}$.

One patient (case 39) was withdrawn from the trial after three days' minoxidil treatment because of the development of new ECG changes suggesting further anterolateral ischaemia; at this time his diastolic blood pressure had fallen from 120 to $90 \mathrm{~mm} \mathrm{Hg}$. The ECG changes reverted to normal within 24 hours of stopping minoxidil treatment and the blood pressure increased. Repeated estimations of serum cardiac enzymes showed normal values. One patient (case 15) was lost to follow-up and another (case 9) stopped taking minoxidil because of drowsiness and lethargy.

TABLE I-Diagnosis, treatment, and supine blood pressures before and during minoxidil treatment

\begin{tabular}{|c|c|c|c|c|c|c|c|c|c|}
\hline \multirow[b]{2}{*}{$\begin{array}{l}\text { Case } \\
\text { No }\end{array}$} & \multirow[b]{2}{*}{$\begin{array}{l}\text { Age } \\
\text { and } \\
\text { sex }\end{array}$} & \multirow[b]{2}{*}{ Diagnosis } & \multicolumn{3}{|c|}{ Before minoxidil } & \multicolumn{4}{|c|}{ During minoxidil } \\
\hline & & & $\underset{(\mathrm{mmol} / \mathrm{l})}{\text { Urea }}$ & Treatment & $\begin{array}{c}\text { Mean } \\
\text { outpatient } \\
\text { blood } \\
\text { pressure } \\
(\mathrm{mm} \mathrm{Hg})\end{array}$ & $\begin{array}{c}\text { Minoxidil } \\
\text { dose } \\
\text { (mg/day) }\end{array}$ & $\begin{array}{l}\text { Other drugs } \\
\text { (and doses, mg/day) }\end{array}$ & $\begin{array}{c}\text { Latest } \\
\text { outpatient } \\
\text { blood } \\
\text { pressure } \\
(\mathrm{mm} \mathrm{Hg})\end{array}$ & $\begin{array}{l}\text { Months on } \\
\text { minoxidil }\end{array}$ \\
\hline $\begin{array}{r}1 \\
2 \\
3 \\
4 \\
5 \\
6 \\
7 \\
8 \\
9 \\
10 \\
11 \\
12 \\
13 \\
14 \\
15 \\
16 \\
17 \\
18 \\
19 \\
20 \\
21 \\
22 \\
23 \\
24 \\
25 \\
26 \\
27 \\
28 \\
29 \\
30\end{array}$ & $\begin{array}{l}30 \mathrm{M} \\
38 \mathrm{~F} \\
52 \mathrm{~F} \\
60 \mathrm{M} \\
57 \mathrm{M} \\
51 \mathrm{M} \\
45 \mathrm{M} \\
55 \mathrm{M} \\
54 \mathrm{M} \\
60 \mathrm{M} \\
40 \mathrm{M} \\
46 \mathrm{M} \\
37 \mathrm{~F} \\
53 \mathrm{M} \\
44 \mathrm{~F} \\
34 \mathrm{~F} \\
66 \mathrm{~F} \\
32 \mathrm{M} \\
63 \mathrm{M} \\
52 \mathrm{M} \\
45 \mathrm{M} \\
59 \mathrm{M} \\
52 \mathrm{M} \\
69 \mathrm{~F} \\
48 \mathrm{M} \\
46 \mathrm{M} \\
46 \mathrm{M} \\
54 \mathrm{M} \\
44 \mathrm{M} \\
51 \mathrm{M}\end{array}$ & 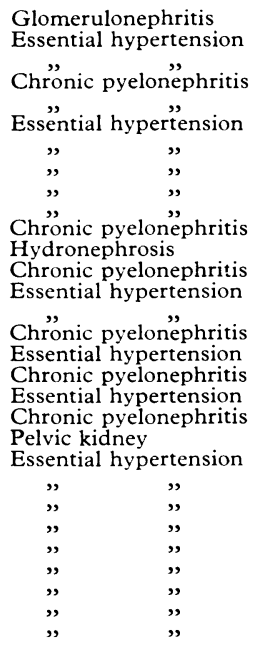 & $\begin{array}{r}16 \cdot 7 \\
10 \cdot 0 \\
7 \cdot 7 \\
18 \cdot 4 \\
19 \cdot 7 \\
5 \cdot 0 \\
14 \cdot 0 \\
26 \cdot 1 \\
5 \cdot 7 \\
4 \cdot 5 \\
19 \cdot 5 \\
9 \cdot 4 \\
15 \cdot 0 \\
7 \cdot 0 \\
4 \cdot 3 \\
31 \cdot 7 \\
6 \cdot 7 \\
8 \cdot 4 \\
17 \cdot 0 \\
8 \cdot 4 \\
9 \cdot 1 \\
6 \cdot 7 \\
16 \cdot 0 \\
5 \cdot 0 \\
7 \cdot 3 \\
6 \cdot 0 \\
4 \cdot 4 \\
4 \cdot 2 \\
5 \cdot 0 \\
10 \cdot 0\end{array}$ & $\begin{array}{l}\text { Pz } \\
\text { B, C, H, Meth, Ox, T } \\
\text { B, C, Ox, Meth } \\
\text { B, C, H, Meth, Ox, T } \\
\text { C, Meth } \\
\text { C, Dz, H, Meth } \\
\text { Db, Ox, Pz, T } \\
\text { C, Meth } \\
\text { Db, C, Meth, Ox } \\
\text { B, Meth, Ox, T } \\
\text { B, C, Db, Meth, Pz } \\
\text { B, Dz, H, Meth, Ox, T } \\
\text { B, C } \\
\text { C, Meth, } \\
\text { Dz, H, Meth, Ox, Pz, T } \\
\text { B, C, Meth } \\
\text { C, Meth, Pz } \\
\text { C, P } \\
\text { B, Meth } \\
\text { C, Dz, H, P, Ph, T } \\
\text { Am, B, F, L, Meth, S } \\
\text { C, L, P, T } \\
\text { B, Meth, P, T } \\
\text { B, Meth, P, Pz, T } \\
\text { B, Meth, P, T } \\
\text { B, Meth, P, T } \\
\text { C, Meth, Ox, T } \\
\text { Meth, P, Pz, T } \\
\text { B, C, Dz, G, P, Meth, } \\
\text { S, T }\end{array}$ & $\begin{array}{l}210 / 120 \\
180 / 120 \\
220 / 145 \\
210 / 135 \\
218 / 130 \\
210 / 120 \\
246 / 136 \\
248 / 138 \\
240 / 130 \\
260 / 130 \\
240 / 160 \\
240 / 130 \\
180 / 120 \\
225 / 115 \\
250 / 148 \\
180 / 120 \\
230 / 130 \\
170 / 130 \\
240 / 130 \\
210 / 110 \\
270 / 150 \\
217 / 137 \\
237 / 143 \\
223 / 119 \\
188 / 132 \\
221 / 134 \\
212 \\
190 / 133 \\
187 \\
212 \\
129\end{array}$ & $\begin{array}{l}15 \\
30 \\
10 \\
60 \\
10 \\
10 \\
30 \\
30 \\
30 \\
30 \\
50 \\
30 \\
35 \\
50 \\
35 \\
35 \\
25 \\
40 \\
40 \\
45 \\
30 \\
20 \\
20 \\
2 \cdot 5 \\
30 \\
20 \\
30 \\
30 \\
20 \\
30\end{array}$ & $\begin{array}{l}\text { F (1000), Ox (80) } \\
\text { F (500), Ox (640) } \\
\text { F (120), P (120) } \\
\text { F (80), Ox (800) } \\
\text { T, P (240) } \\
\text { T, Ox (320) } \\
\text { F (80), Ox (960) } \\
\text { F (160), P (80) } \\
\text { T, P (320) } \\
\text { F (40), P (240) } \\
\text { F (500), P (320) } \\
\text { F (120), P (800) } \\
\text { F (1000), P (640) } \\
\text { T, P (960) } \\
\text { F (40), P (320) } \\
\text { F (2000), Ox (1120) } \\
\text { F (160), P (120) } \\
\text { F (40), Ox (1920) } \\
\text { F (750), P (480) } \\
\text { F (500), P (320), S (100) } \\
\text { T, P (320) } \\
\text { Am (10), L (400) } \\
\text { T, L (1600) } \\
\text { T, P (480) } \\
\text { T, L (400) } \\
\text { T, P (480) } \\
\text { T, B (100), P (320) } \\
\text { S (200), L (800) } \\
\text { T, P (320) } \\
\text { T, P (400) }\end{array}$ & $\begin{array}{l}130 / 80 \\
155 / 90 \\
150 / 98 \\
170 / 95 \\
135 / 85 \\
130 / 90 \\
180 / 100 \\
170 / 100 \\
160 / 80 \\
160 / 105 \\
190 / 120 \\
120 / 70 \\
140 / 90 \\
150 / 100 \\
185 / 90 \\
145 / 90 \\
140 / 80 \\
140 / 90 \\
170 / 105 \\
170 / 80 \\
170 / 100 \\
166 / 92 \\
170 / 100 \\
218 / 100 \\
142 / 90 \\
132 / 86 \\
140 / 88 \\
118 / 82 \\
146 / 100 \\
156 / 98\end{array}$ & $\begin{array}{l}11 \\
2 \\
23 \\
16 \\
21 \\
11 \\
16 \\
24 \\
16 \\
22 \\
23 \\
16 \\
12 \\
11 \\
13 \\
16 \\
17 \text { days } \\
10 \\
23 \\
13 \\
13 \\
11 \\
12 \\
20 \\
16 \\
18 \\
18 \\
11 \\
5 \\
22\end{array}$ \\
\hline $\begin{array}{l}31 \\
32 \\
33 \\
34 \\
35 \\
36 \\
37 \\
38 \\
39 \\
40 \\
41\end{array}$ & $\begin{array}{l}51 \mathrm{M} \\
50 \mathrm{M} \\
44 \mathrm{M} \\
51 \mathrm{M} \\
57 \mathrm{~F} \\
48 \mathrm{~F} \\
61 \mathrm{M} \\
49 \mathrm{~F} \\
63 \mathrm{M} \\
47 \mathrm{M} \\
40 \mathrm{~F}\end{array}$ & $\begin{array}{c}\text { ", } \\
\text { ", } \\
\text { ", } \\
\text { Renal artery stenosis } \\
\text { Essential hypertension } \\
\text {," } \\
\text { ", } \\
\text { ", }\end{array}$ & $\begin{array}{r}8 \cdot 0 \\
14 \cdot 8 \\
6 \cdot 5 \\
6 \cdot 4 \\
5 \cdot 5 \\
15 \cdot 5 \\
36 \cdot 2 \\
4 \cdot 9 \\
5 \cdot 2 \\
17 \cdot 3 \\
6 \cdot 6\end{array}$ & $\begin{array}{l}\text { B, F, Meth, P, Pz, T } \\
\text { F, L, Meth, P, T } \\
\text { B, Meth, P, Pz, T } \\
\text { B, C, Dz, Meth, P, Pz, T } \\
\text { B, H, Meth, Met, T } \\
\text { B, L, Meth, P, S, T } \\
\text { B, F, L, Meth, P, T } \\
\text { L, Meth, T } \\
\text { B, Meth, P, T } \\
\text { B, G, H, Meth, P, S, T } \\
\text { B, G, H, Meth, P, Pz, }\end{array}$ & 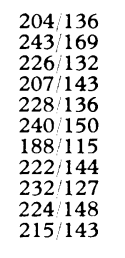 & $\begin{array}{l}15 \\
30 \\
50 \\
30 \\
2 \cdot 5 \\
20 \\
10 \\
5 \\
12 \cdot 5 \\
5 \\
15\end{array}$ & $\begin{array}{l}\mathrm{F}(160), \mathrm{P}(80) \\
\mathrm{F}(160), \mathrm{P}(160) \\
\text { T, L }(2400) \\
\text { T, L (1600) } \\
\text { F'(40), Met }(100), \mathrm{S}(100) \\
\mathrm{F}(120), \mathrm{P}(40) \\
\mathrm{F}(500), \mathrm{L}(400) \\
\text { T, P (80) } \\
\text { T, P (300) } \\
\text { T, P (720), B (60) } \\
\text { T, P }(1440)\end{array}$ & $\begin{array}{l}148 / 90 \\
192 / 122 \\
158 / 106 \\
152 / 94 \\
196 / 114 \\
168 / 86 \\
200 / 120 \\
128 / 82 \\
175 / 100 \\
150 / 90 \\
180 / 105\end{array}$ & $\begin{array}{c}4 \\
6 \\
16 \\
14 \\
2 \\
2 \\
1 \\
1 \\
3 \text { days } \\
4 \\
4\end{array}$ \\
\hline 42 & $60 \mathrm{~F}$ & $"$ & $7 \cdot 2$ & $\mathrm{~B}, \mathrm{G}, \mathrm{H}$, Meth, P, Pz, & 248128 & 25 & $\mathrm{~T}, \mathrm{P}(1280)$ & $230 / 138$ & 2 \\
\hline $\begin{array}{l}43 \\
44\end{array}$ & $\begin{array}{l}41 M \\
36 M\end{array}$ & $\begin{array}{l}\text { Renal artery stenosis } \\
\text { Essential hypertension }\end{array}$ & $\begin{array}{l}5 \cdot 9 \\
4 \cdot 9\end{array}$ & $\begin{array}{l}\text { B, C, P, Meth, Pz, T } \\
\text { B, C, Dz, F, G, H, } \\
\text { Meth, P, Ph, Pz, S, T }\end{array}$ & $\begin{array}{l}232 / 134 \\
237 / 147\end{array}$ & $\begin{array}{l}30 \\
40\end{array}$ & $\begin{array}{l}\mathrm{T}, \mathrm{L}(1600) \\
\mathrm{T}, \mathrm{P}(240)\end{array}$ & $\begin{array}{l}174 / 100 \\
240 / 155\end{array}$ & $\begin{array}{l}4 \\
2\end{array}$ \\
\hline
\end{tabular}

Am $=$ Amiloride $\mathrm{B}=$ Bethanidine $\mathrm{C}=$ Clonidine $\mathrm{Db}=$ Debrisoquine. $\mathrm{Dz}=$ Diazoxide. $\mathrm{F}=$ Frusemide. $\mathrm{G}=\mathrm{Guanethidine}$. $\mathrm{H}=\mathrm{Hydrallazine}$. $\mathrm{L}=\mathrm{Labetalol}$ Meth $=$ Methyldopa. Am $=$ Amiloride. $\mathrm{B}=$ Bethanidine. $\mathrm{C}=$ Clonidine. $\mathrm{Db}=$ Debrisoquine. $\mathrm{Dz}=$ Diazoxide. $\mathrm{F}=$ Frusemide. $\mathrm{G}=\mathrm{Guanethidine}$. $\mathrm{H}=\mathrm{Hydrallazine}$. $\mathrm{L}=\mathrm{Labetal}$ 
Hirsuties was an invariable finding. While acceptable to the men this was a major inconvenience for the women, three of whom (cases 17, 41, and 42) would not continue with the trial. Left ventricular failure occurred in three patients but was readily controlled by increasing the dose of diuretic without stopping minoxidil. Gynaecomastia occurred in three men (cases 11, 12, and 20), all of whom continued with the treatment.

\section{LABORATORY INVESTIGATIONS}

Twenty-two patients had normal renal function before the trial (table I) and there were no significant changes during minoxidil treatment. Before starting their mean serum urea concentration $( \pm \mathrm{SD})$ was $5 \cdot 7 \pm 1.0 \mathrm{mmol} / 1(34 \pm 6 \mathrm{mg} / 100 \mathrm{ml})$ and creatinine $106 \pm 31 \mu \mathrm{mol} / 1(1 \cdot 20 \pm 0.4 \mathrm{mg} / 100 \mathrm{ml})$; during minoxidil treatment mean urea was $6 \cdot 1 \pm 1.3 \mathrm{mmol} / 1(37 \pm 8 \mathrm{mg} / 100 \mathrm{ml})$ and creatinine $110 \pm 31 \mu \mathrm{mol} / 1(1.24 \pm 0.4 \mathrm{mg} / 100 \mathrm{ml})$. In the remaining 22 patients renal function was initially impaired and remained unchanged during minoxidil treatment. Before starting minoxidil their mean serum urea concentration was $15.9 \pm 7.6 \mathrm{mmol} / \mathrm{l}(96 \pm 46 \mathrm{mg} / 100 \mathrm{ml})$ and creatinine $328 \pm 196 \mu \mathrm{mol} 1(3 \cdot 71 \pm 2 \cdot 2 \mathrm{mg} 100 \mathrm{ml})$; during minoxidil therapy mean serum urea was $17 \cdot 0 \pm 7 \cdot 5 \mathrm{mmol} / 1(102 \pm 45 \mathrm{mg} / 100 \mathrm{ml})$ and creatinine $331 \pm 173 \mu \mathrm{mol} / 1(3 \cdot 74 \pm 2 \cdot 0 \mathrm{mg} / 100 \mathrm{ml})$. There were no significant changes in the haemoglobin concentration or white cell count in either group.

In two patients, however, the platelet count dropped to $100 \times 10^{9} / 1$ and to $150 \times 10^{9} /$. Serum cardiac enzyme values remained normal in all the patients studied, both while in the ward and at subsequent outpatient attendances. During previous treatment with diazoxide the blood sugar concentration had risen in seven patients, but in each case it reverted to normal on minoxidil. During the first four days of inpatient management, when the dose of minoxidil was being increased rapidly, ECGs were recorded daily, and except in case 39 new changes were not noted. No systematic ECG changes were found throughout the remainder of the study.

\section{Discussion}

A reduction of blood pressure in patients with diastolic pressures greater than $120 \mathrm{~mm} \mathrm{Hg}$ leads to an increased survival, mainly owing to a reduced incidence of stroke. ${ }^{7}$ × All our patients had maintained blood pressures of over $120 \mathrm{~mm} \mathrm{Hg}$ despite treatment with the usual hypotensive drugs. Although oral diazoxide has been effective in such patients, ${ }^{910}$ it is not always successful and has complications. ${ }^{11}$ Bilateral nephrectomy is sometimes contemplated in these circumstances. ${ }^{12}$ Therefore any drug that lowers blood pressure in such patients, without producing major side effects, would constitute a distinct therapeutic advance.

We have found minoxidil, in combination with a beta-blocker and diuretic, to be highly effective as maintenance hypotensive treatment in most of our patients, including those with terminal renal failure. Other hypotensive drugs were, however, needed to maintain satisfactory blood pressure control in 11 patients: labetalol was substituted for propranolol in eight cases and methyldopa, bethanidine, or prazosin were added in the remaining three cases.
The development of hirsuties is a problem in women treated with minoxidil. This difficulty has now been overcome by the use of a properly applied depilatory cream ("Butto," Wright, Layman, and Umney), and two of the women who had refused to continue with minoxidil resumed treatment. Their blood pressures again fell to acceptable levels.

We have no evidence that the four deaths in this series were related to the treatment. Although two patients died of presumed myocardial infarction, treatment of hypertension does not reduce the incidence of this complication. ${ }^{13}$ Minoxidil has been shown in beagles to have an unusual cardiotoxic effect peculiar to the right atrium ${ }^{14}$; in the only patient who came to necropsy in this study the right atrium was not examined histologically.

In conclusion, minoxidil is a most effective hypotensive agent, but because of its potentially serious side effects it should be limited to patients with severe hypertension who are unresponsive to conventional treatment or suffer intolerable side effects from it.

We thank Dr Hazel Hinchley of Upjohn Limited for supplies of minoxidil and financial support, and Mrs A A Aitken, Beauty Care Officer of the British Red Cross, for her help in the management of hirsuties in the women.

Requests for reprints should be addressed to the Secretary, Glasgow Blood Pressure Clinic, Department of Medical Computing, Western Infirmary, Glasgow G11 6NT.

ADDENDUM-Since this paper was written the death has occurred of case 35 with respiratory failure due to chronic bronchitis and emphysema. Blood pressure was well controlled before death and necropsy showed no abnormality in the right atrium comparable to that found in dogs treated with minoxidil.

\section{References}

${ }^{1}$ British Medical fournal, 1973, 4, 185

2 Gilmore, E, Wiel, J, and Chidsey, C, New England fournal of Medicine, 1970, 282, 521 .

${ }^{3}$ Pettinger, W A, and Mitchell, H C, New England fournal of Medicine, 1973, 289, 167.

4 Limas, C J, and Freis, E D, American fournal of Cardiology, 1973, 31, 355.

${ }^{5}$ Dormois, M D, Young, J J, and Nies, A S, American Heart fournal, 1975, 90, 360.

' Page, L B, Yagar, H M, and Sidd, J J, American Heart fournal, 1976, 92, 252.

' Hamilton, M, Thompson, E N, and Wisneiwski, T K M, Lancet, 1964, 1, 235.

* Veterans Administration Co-operative Study Group in Antihypertensive Agents, Fournal of the American Medical Association, 1967, 202, 1028.

${ }^{9}$ Pohl, J E F, and Thurston, H, Lancet, 1972, 1, 1231.

10 Kincaid-Smith, P, Lancet, 1973, 1, 551.

${ }^{11}$ De Broe, M, et al, Lancet, 1972, 1, 1397.

12 Mahony, J F, et al, Lancet, 1972, 1, 1036.

${ }_{13}$ Beevers, D G, et al, Postgraduate Medical fournal, 1973, 49, 905.

${ }^{14} \mathrm{Du}$ Charme, D W, et al, fournal of Pharmacology and Experimental Therapeutics, 1973, 184, 662.

(Accepted 21 fuly 1977) 